УДК. 373.5.016:796-047.64(045)

DOI 10.31339/2617-0833-2019-1(26)-92-97

ОПТИМІЗАЦІЯ УПРАВЛІННЯ СИСТЕМОЮ ФІЗИЧНОГО ВИХОВАННЯ В ЗАКЛАДАХ ЗАГАЛЬНОЇ СЕРЕДНЬОЇ ОСВІТИ

Гавришко С. Г., Кобаль В. І.

\title{
THE OPTIMIZATION OF MANAGEMENT OF THE PHYSICAL EDUCATION SYSTEM IN INSTITUTIONS OF SECONDARY EDUCATION
}

Havryshko Serhii, Kobal Vasyl

На даний час відсутній системний підхід до організаиії роботи з фізичного виховання в школі, щзо вимагає необхідність розробки нових, адекватних вимогам часу $i$ тенденціям розвитку суспільства, форм, засобів $i$ методів фізкультурно-оздоровчої $i$ позакласної роботи в закладах загальної середньої освіти.

Проблеми ефективності системи фізичного виховання учнівської молоді були предметом дослідження В.В. Григораша, Л.В.Волкова, О.С.Куча, Т.Ю.Круцевич, В. Г. Папуші, Б. М. Шияна та інших. Водночас в иій сфері залишається невирішеною проблема ефективності організації і керівництва системою фізичного виховання у закладах загальної середньої освіти.

Мета дослідження - визначити иляхи підвищення ефективності управління системою фізичного виховання в закладі загальної середньої освіти.

Аналіз дослідження ставлення до системи фізичного виховання у школі школярів та батьків показав, що більшість батьків $і$ учнів позитивно ставиться до занять фізкультурою, але існує значна частка (25\%) тих, хто не вважає систематичне виконання фізичних вправ корисними для здоров'я, тому що вони відволікають від основного навчання.

Результати досліджень показали, щзо обсяг рухової активності у 69,4\% опитаних учнів складає 3-4 години на тиждень і є недостатнім для дітей цьього віку. Для підтримки на належному рівні всіх фізичних якостей необхідно 4-6 годин на тиждень, а для їхнього розвитку - 7-10 годин на тиждень.

Одним із шляхів оптимізаиї системи фізичного виховання $\epsilon$ підвищення ефективності ї управління. Тому нами запропонована модель управління системою фізичного виховання в закладах загальної середньої освіти.

Для збільшення обсягу рухової активності учнів в умовах школи пропонується комплексно використовувати різні форми роботи з фізичного виховання, особливу увагу звернувщи на якісне проведення уроків фізкультури, забезпечення відповідального ставлення педагогів $і$ учнів до форм роботи протягом навчального дня та активізацію активного дозвілля в школі.

Дослідження показало, щзо ефективність запропонованих нами иляхів оптимізація управління системою фізичного виховання в закладах загальної середньої освіти можна досягнути за умови використання ефективної моделі управління, необхідності застосування усієї системи форм роботи з фізичного виховання та результатів діагностики наявних виховних можливостей всього педагогічного колективу.

Ключові слова: фізична культура, система фізичного виховання.

Currently, there is no systematic approach to the organisation of work on physical education in schools, which requires the development of new suitable to the demands of time and tendencies in society, forms, ways and methods of physical culture recreation and extracurricular work in establishments of secondary education.

Problems of effectiveness of the system of physical education of students were the subject of the research V. V. Hrihorash, L. V. Volkov, O. S. Kuts, T. Y. Papusy, B. M. Shyan and others. At the same time there is another unresolved issue concerning the effectiveness the organisation and 
management in institutions of secondary education.

The aim of the research is to determine the ways to improve management of the system of physical education in establishments of secondary education.

The analysis of the attitude of schoolchildren and their parents towards the system of physical education at the school showed that most parents and pupils have a positive attitude towards physical education, but there is a significant part (25\%) of those who don't consider the systematic exercise of physical exercises to be beneficial for health, because they distract from education.

The result of research showed that the volume of motor activity of 69,4\% responded pupils is 3-4 hours per week and that is not enough for children of this age. To maintain the proper level of all physical qualities it's necessary to allocate 4-6 hours per week and for their development 710 hours per week.

One of the ways to optimise the system of physical education is improving its management. Therefore, there is a model of management of the physical education system in institutions of secondary education.

In order to increase the volume of motor activity of pupils in school conditions, it has been proposed to use various forms of physical education in complex way paying special attention to high-quality physical education classes, ensuring a responsible attitude of teachers and pupils towards forms of work during the school day and intensifying leisure activities at school.

The research showed that the effectiveness of our suggested ways to optimise the management of physical education in institutions of secondary education can be achieved by using an effective model of management, the need

of the use of the entire system of forms of work on physical education and the result of diagnostic of the existing trained opportunities of the entire pedagogical team.

Key words: physical culture, the system of physical education

Проблема здоров'я людини, за своєю практичною значимістю, вважається однією 3 найскладніших проблем сучасної цивілізації, адже здоров'я є головним фактором у будь-якій сфері суспільної діяльності людини. Тому одним із важливих завдань держави у галузі освіти $\epsilon$ забезпечення умов для збереження здоров'я нації та виховання всебічно розвинутого підростаючого покоління [1]. Цим зумовлена необхідність підвищення ефективності організації фізичного виховання у загальноосвітніх навчальних закладах України та використання ефективних освітніх і виховних методик, що забезпечують мотивацію школярів до рухової активності [2].

Аналіз проведених досліджень за останні роки свідчить про значне погіршення стану здоров'я населення України. Однією з основних причин такого явища $є$ те, що система форм роботи 3 фізичного виховання в закладах загальної середньої освіти не забезпечує необхідний обсяг рухової активності молоді. Глобальна важливість і актуальність даної проблеми викликає необхідність подальшого дослідження феномену здоров'я, форм роботи 3 фізичного виховання молоді та пошуку шляхів покращення управління цією системою [3]. Вирішення цих проблем у значній мірі пов'язується із забезпечення необхідних умов та ефективного керівництва системою фізичного виховання підростаючого покоління.

Проблеми ефективності системи фізичного виховання учнівської молоді були предметом дослідження В.В. Григораша, Л.В. Волкова, О.С. Куца, Т.Ю. Круцевич, В. Г. Папуші, Б. М. Шияна та інших. Водночас в цій сфері залишається достатньо невирішених проблем. Зокрема, у забезпеченні ефективності організації і керівництва системою фізичного виховання у закладах загальної середньої освіти [4].

Метою статті є визначити шляхи підвищення ефективності управління системою фізичного виховання в закладі загальної середньої освіти.

Фізичне виховання учнів в закладах загальної середньої освіти - предмет особливої уваги як у теорії педагогіки, так і в методиці. Це пов'язано з тим, що саме в шкільному віці 
формуються основні фізичні якості людини, знання, уміння та навички. Відомо, що у цьому віці велика потреба учнів у руховій діяльності, а тому необхідно ефективніше формувати у них прагнення до фізичного вдосконалення.

Система фізичного виховання в закладах освіти в цілому спроможна забезпечити належне фізичне вдосконалення молодого покоління, зберегти і примножити його здоров'я як найвищу цінність особистості.

Разом 3 тим, в теперішніх умовах, обов'язкові для усіх школярів уроки фізичної культури лише на 11 - 13\% компенсують необхідний добовий обсяг рухів [5]. До того ж вони не формуються у школярів звички до систематичних занять фізичними вправами, не дають достатніх знань у галузі фізичної культури. Інші ж форми роботи проводяться епізодично, що ще більше ускладнюють можливість вирішення завдань фізичного виховання.

Результати дослідження, проведених у загальноосвітніх школах України [6;7;8] свідчать, що наші школярі страждають від недостатньої рухової активності. Наслідком гіпертензії $є$ так звана хронічна шкільна втома. У дітей погіршується зір, знижується кількість еритроцитів у крові, сповільнюється ріст, помітно знижується розумова працездатність та погіршується здоров'я в цілому.

Встановлено, що хворобливі зміни у стані здоров'я школярів викликані не лише навчальним перевантаженням, а й особливостями організацією їхнього вільного часу. Однією з причин різноманітних відхилень у фізичному розвитку і стані здоров'я $є$ недостатня рухова активність, обсяг якої з кожним роком зменшуються [9].

Тому, без комплексного підходу до вирішення основних завдань фізичного виховання молоді, оптимізації управління та забезпечення умов функціонування системи фізичного виховання результативність значно знижена.

Проведення спостереження на уроках фізкультури, аналіз форм роботи в режимі навчального дня, під час проведення позакласної фізкультурно-оздоровчої роботи та опитування вчителів свідчать про те, що не всі вони чітко розуміють значення для учнів занять фізичною культурою. Недостатніми виявилися їхні знання щодо впливу та користі занять фізичними вправами в позаурочний час.

3 метою дослідження ставлення школярів та батьків до системи фізичного виховання у школі нами проведено анкетування.

Аналіз відповідей показав, що більшість батьків і учнів позитивно ставиться до занять фізкультурою, але існує значна частка (25\%) тих, хто не вважає систематичне виконання фізичних вправ корисними для здоров'я, тому що вони відволікають від основного навчання.

Виявилося, що існує і така частина батьків $(9 \%)$, які вважають фізичне виховання шкідливим для здоров'я своїх дітей і намагаються всілякими шляхами звільнити свої «чада» від уроків фізкультури.

Аналіз відповідей про організацію вільного часу учнів показав, що більшість дітей віддає перевагу малорухливим видам діяльності таким, як - перегляду телепередач (35,2\%), комп'ютерним іграм $(22,3 \%)$, читанню книг $(18,2 \%)$, тобто тим видам діяльності, які несприятливо впливають на організм, викликаючи систематичну напругу.

Результати досліджень показали, що обсяг рухової активності у 69,4\% опитаних дітей складає 3-4 години на тиждень і є недостатнім для учнів цього віку. Для підтримки на належному рівні всіх фізичних якостей необхідно 4-6 годин на тиждень, а для їхнього розвитку - 7-10 годин на тиждень.

Набутий емпіричний матеріал дозволяє стверджувати, що ознакою нинішнього часу $\epsilon$ те, що в системі стимулюючих засобів сімейно-родинного виховання відсутня орієнтація на фізкультурно-оздоровчої діяльності в умовах школи і сім'ї.

Результати анкетування засвідчують, що особистий приклад батьків - це найкращий засіб залучення дітей до систематичних занять фізичною культурою та спортом. Це визначає 70,9\% респондентів, одночасно 10,8\% - не погоджується 3 цим твердженням. У числі 
опитаних батьків лише 9,6\% систематично займається фізичною культурою, 19,2\% нерегулярно, 41,8\% займається фізичною культурою епізодично і 29,4\% респондентів не займається фізичною культурою.

Дослідження показало, що ставлення до фізичної культури та спорту значно залежить від наявності умов і інвентарю, який $є$ вдома. Аналіз відповідей показав, що практично в усіх сім'ях є певний спортивний інвентар. Виняток складають лише 4,51\% опитаних сімей. Найчастіше зустрічається такий інвентар: м'ячі $(71,18 \%)$, велосипед $(65,15 \%)$, лижі $(40,6 \%)$, ролики $(30,06 \%)$, гантелі $(36,06 \%)$, інвентар для гри в бадмінтон $(59,27 \%)$. Дещо менш розповсюджений такий спортивний інвентар, як штанга $(12,7 \%)$ та туристичні спорядження (16,66\%). Ще в меншій кількості розповсюдженні тренажери $(3,03 \%)$, перекладена $(3,03 \%)$, гімнастичні бруси $(1,51 \%)$.

Таким чином, кількість спортивного інвентарю в сім'ях достатня та різноманітна. Лише невеликий відсоток батьків не забезпечує дітей спортивним обладнання і інвентарем. При свідомому та активному сприянні батьків заняття фізичними вправами можуть перерости у природну потребу кожної дитини. Разом з тим батьки повинні це усвідомити. Тут велика роль відводиться школі, яка доступними ій засобами повинна переконати батьків, що майбутнє щастя, здоров'я, життєдіяльність та життєстійкість молоді, багато в чому залежить від їх повноцінного фізичного розвитку і фізичного виховання.

Загальновідомо, що головна роль в системі національного виховання в цілому і фізичного виховання зокрема, належить школі і родині, де в поєднанні виховного впливу на учнів вони органічно взаємопов'язані шкільною позакласною і позашкільною роботою, тобто об’єднанні спільною діяльністю.

Нами була розроблена модель управління системою фізичного виховання в закладах загальної середньої освіти (рис.1).

\begin{tabular}{|c|c|c|c|c|c|}
\hline $\begin{array}{l}\text { Визначення } \\
\text { мети системи } \\
\text { фізичного } \\
\text { виховання в } \\
\text { закладі } \\
\text { середньої } \\
\text { освіти та } \\
\text { зіставлення їі з } \\
\text { умовами праці }\end{array}$ & $\rightarrow$ & $\begin{array}{l}\text { Проектування } \\
\text { результатів та } \\
\text { визначення } \\
\text { навчання, } \\
\text { оздоровлення і } \\
\text { виховання } \\
\text { завдань }\end{array}$ & $\rightarrow \mid \begin{array}{l}\text { Забезпечення } \\
\text { системи } \\
\text { педагогічного } \\
\text { впливу (система } \\
\text { форм роботи, } \\
\text { ефективні } \\
\text { засоби, } \\
\text { адекватні } \\
\text { методи) }\end{array}$ & $\begin{array}{l}\text { Контроль ходу } \\
\text { педагогічного } \\
\text { процесу } \\
\text { (рівень } \\
\text { соматичного } \\
\text { здоров'я та } \\
\text { фізичної } \\
\text { підготовленості) }\end{array}$ & $\rightarrow \begin{array}{l}\text { Підсумковий } \\
\text { контрольний } \\
\text { облік і аналіз }\end{array}$ \\
\hline
\end{tabular}

Пропонована нами модель управління включає ряд послідовних операцій, а саме:

1. Врахувавши конкретні умови праці, рівень підготовленості учнів та індивідуальні особливості педагогів, необхідно здійснити корекцію мети-ідеалу. Після цього трансформувати iї в тактичну та оперативну мету.

2. Потім здійснити проектування бажаного стану рівнів теоретичної, фізичної i технічної підготовки у вигляді певних результатів. Щоб досягти бажаного стану потрібно визначити конкретні завдання щодо теоретичної інформації, виховання фізичних якостей, опанування фізичних вправ передбачених шкільною програмою, врахування оздоровчих $\mathrm{i}$ виховних завдань.

3. Для розв'язання поставлених завдань педагог визначає систему педагогічного впливу на учнів, а саме - засоби, методи та форми роботи, а також сприяє забезпеченню необхідних умов функціонування системи фізичного виховання в закладі загальної середньої освіти.

4. Необхідно при цьому врахувати несприятливі фактори, що будуть заважати правильній організації процесу фізичного виховання. Це насамперед, негативне ставлення 
батьків або педагогів, друзів до фізичного виховання, порушення режиму дня, шкідливі звички.

5. Для перевірки правильності функціонування системи фізичного виховання в закладі середньої загальної освіти необхідно використовувати систему поетапного контролю за допомогою тестів оцінки знань, умінь, навичок, а також рівня соматичного здоров'я i фізичної підготовленості. В кінці слід провести комплексний аналіз та розробити практичні рекомендації.

Для покращення ефективності управління системою фізичного виховання в закладах загальної середньої освіти необхідно збільшити обсяг рухової активності учнів в умовах школи із залученням всього педагогічного колективу і батьків[3;4]. Для цього ми пропонуємо використовувати комплексно різні форми роботи 3 фізичного виховання особливу увагу звернувши на якісне проведення уроків фізкультури, забезпечення відповідального ставлення педагогів і учнів до форм роботи протягом навчального дня та активізацію активного дозвілля в школі. Нами був застосований комплекс дитячих спортивних змагань «Старти здоров'я», активізовано проведення години здоров'я та використовувались спортивні розваги у позаурочний час. Впровадження та оптимізація цих форм роботи дозволили досягти певних позитивних зрушень.

Таким чином ефективність запропонованих нами шляхів оптимізація управління системою фізичного виховання в закладах загальної середньої освіти можна досягнути за умови врахування навчально-виховних завдань, необхідності використання системи форм роботи 3 фізичного виховання, вікових особливостей учнів та результатів діагностики наявних виховних можливостей всього педагогічного колективу.

\section{Список використаних джерел}

1. Ярчук Ю.Г. Формування культури здорового способу життя в системі пріоритетів державної освітньої політики / Ю.Г. Ярчук // Науковий часопис Національного педагогічного університету імені М.П.Драгоманова. Серія 7. Релігієзнавство. Культурологія. Філософія: [зб. наукових праць] / ред. рада: В. П. Андрущенко (голова). - К.: Видавництвово НПУ імені М. П. Драгоманова, 2013. - Вип. 29 (41). - С. 226-229.

2. Франків Є. Є. Мотивація рухової активності школярів / Є. С. Франків, І. М. Григус // Теорія та методика фізичного виховання. - 2012. - №6. - С.15-18.

3. Михно Л. С. Інновації як чинник підвищення ефективності навчально-виховної та фізкультурно-оздоровчої роботи вчителя / Л. С. Михно // Фізичне виховання в сучасній школі. - 2012. - №5. - С.13-18.

4. Шиян Б. М. Теорія і методика фізичного виховання школярів. Частина 1 : підручник для студ. ВНЗ. Доп. МОНУ / Б. М. Шиян. - Тернопіль : Навчальна книга - Богдан, 2001. $-272 \mathrm{c}$.

5. Абрамов В. Рухова активність і здоров'я. Оцінка рівня здоров'я дітей шкільного віку / В. Абрамов, Ю. Борисов // Концепція розвитку галузі фізичного виховання і спорту в Україні: збірник наукових праць. - Рівне: РВЦ Міжнародного університету «РЕГГ» імені академіка Степана Дем'янчука, 2003. - Ч. 1. - С. 122-126.

6. Горащук В.П. Культура здоров'я - новий сучасний напрям формування здорового покоління / В.П. Горащук // Проблеми освіти: наук.-метод. зб. - К.: Інститут інноваційних технологій і змісту освіти, 2006. - Вип. 48. - С. 184-189.

7. Карпюк Р. Формування позитивної мотивації на здоровий спосіб життя у дітей та молоді в контексті вивчення шкільного предмета "Основи здоров'я" / Р. Карпюк, О. Петрик // Педагогічний часопис Волині. - 2016. - № 2. - С. 114-119. 
8. Петрик О.І. Медико-біологічні та психолого-педагогічні основи здорового способу життя. Курс лекцій: навч. посіб. [для студ. ун-тів та пед. ін-тів] / О.І. Петрик. - Львів: Світ, 1993. - 119 с.

9. Соколенко Л. Сучасні тенденції формування культури здорового способу життя в процесі підготовки майбутніх фахівців /Л. Соколенко // Проблеми підготовки сучасного вчителя. - 2014. - № 10(2). - С. 193-199.

\section{References}

1. Yarchuk, Yu.H., 2013. Formuvannia kultury zdorovoho sposobu zhyttia v systemi priorytetiv derzhavnoi osvitnoi polityky [Formation of a healthy lifestyle culture in the system of priorities of state educational policy]. Scientific Bulletin of the National Pedagogical University named after M.P. Drahomanov. Series 7. Religious studies. Culturology. Philosophy, 29 (41), pp. 226-229.

2. Frankiv, Ye. Ye., 2012. Motyvatsiia rukhovoi aktyvnosti shkoliariv [Motivation of motor activity of schoolchildren]. Theory and methods of physical education, 6, p. 15-18.

3. Mihno, L.S., 2012. Innovatsiyi yak chynnyk pidvyshchennya efektyvnosti navchal'novykhovnoyi ta fizkul'turno-ozdorovchoyi roboty vchytelya [Innovations as a factor of the effectiveness of the educational and educational and recreational activities of the teacher]. Physical education in the modern school, 5, pp.13-18.

4. Shiyan, B. M. 2001. Teoriya i metodyka fizychnoho vykhovannya shkolyariv. Chastyna 1 [Theory and method of physical education of schoolchildren. Part 1]. Ternopil: Educational book - Bogdan.

5. Abramov, V., Borisov, Yu.V. 2003. Rukhova aktyvnist' i zdorov'ya. Otsinka rivnya zdorov'ya ditey shkil'noho viku [Motor activity and health. Assessment of the health of children of school age]. Concept of development of physical development in Ukraine, 1, pp. 122-126.

6. Horashchuk, V.P., 2006. Kultura zdorovia - novyi suchasnyi napriam formuvannia zdorovoho pokolinnia [The culture of health is a new modern trend for the formation of a healthy generation]. Problems of Education, 48, pp. 184-189.

7. Karpiuk, R., and Petryk, O., 2016. Formuvannia pozytyvnoi motyvatsii na zdorovyi sposib zhyttia u ditei ta molodi v konteksti vyvchennia shkilnoho predmeta "Osnovy zdorovia [Formation of positive motivation for a healthy lifestyle among children and young people in the context of studying the school subject "Fundamentals of Health"]. Pedagogical Journal of Volyn, 2, pp. 114-119.

8. Petryk, O.I. 1993. Medyko-biolohichni ta psykholoho-pedahohichni osnovy zdorovoho sposobu zhyttya. Kurs lektsiy [Medical and biological and psychological and pedagogical bases for a healthy lifestyle. Course of lectures]. Lviv: Svit.

9. Sokolenko, L., 2014. Suchasni tendentsiyi formuvannya kultury zdorovoho sposobu zhyttya $\mathrm{v}$ protsesi pidhotovky maybutnikh fakhivtsiv [Modern trends in the formation of a healthy lifestyle culture in the process of future specialists' training]. Problems of modern teacher training, 10(2), pp. 193-199. 